https://helda.helsinki.fi

\title{
Moral Economy Theory
}

\section{Komp-Leukkunen, Kathrin Susanne}

Springer

2021-12-02

Komp-Leukkunen , K S \& Im , Z J 2021, Moral Economy Theory . in D Gu \& M E Dupre (eds) , Encyclopedia of Gerontology and Population Aging . 2021 Edition edn , Springer , Cham . https://doi.org/10.1007/978-3-030-22009-9_200

http://hdl.handle.net/10138/338633

https://doi.org/10.1007/978-3-030-22009-9_200

unspecified

acceptedVersion

Downloaded from Helda, University of Helsinki institutional repository.

This is an electronic reprint of the original article.

This reprint may differ from the original in pagination and typographic detail.

Please cite the original version. 


\title{
Moral Economy Theory
}

\author{
Affiliation \\ Kathrin Komp-Leukkunen \\ Faculty of Social Sciences, University of Helsinki \\ PO Box 54, 00014 University of Helsinki, Finland \\ kathrin.komp@helsinki.fi \\ Co-author(s) Affiliation \\ Zhen Jie Im \\ Faculty of Social Sciences, University of Helsinki \\ PO Box 18, 00014 University of Helsinki, Finland \\ zhen.im@helsinki.fi
}

\section{Synonyms}

moral reflections on the market; norms concerning economic exchange; ideals of reciprocity

\section{Definition(s)}

Moral economy theory describes shared social norms and moral assumptions underlying forms of economic organization and production. It also describes individuals' perceptions of rights and responsibilities towards other individuals within a similar communityWith respect to old age, moral economy theory focusses especially on the norms and moral assumptions shaping retirement, old age care, and the third age.

\section{Introduction}

Moral economy theory becomes increasingly important as populations age. Population ageing changes the structures of societies, and many wonder how they should best react to this demographic change. The moral economy of aging provides them with a guideline. It describes what society owes older people, and what it could ask from them. As such, it captures the role of older people in society, and it outlines how we could be expected to approach them. This is also akin to reciprocity which had been referred to as one of the social norms underpinning economic organization (Kohli 1987, Götz 2015).

While the term 'moral economy' was only coined in the 1970s, the idea of a moral economy theory existed far longer. For instance, Aristotle's social theory considered economy - household management - to be embedded in a framework of social norms (Götz 2015). Similarly, Thompson (1971) posited that the English food riots in the 18th century were in part fuelled by the breakdown of pre-capitalist social norms and expectations as economic organisation moved towards capitalism. During the economic transformation, ideas of self-interest and profit maximisation gained ground over pre-capitalist social norms. There was widespread popular consensus in pre-capitalist England that prices on staples such as white flour and white bread ought to be be regulated in difficult times. There was also a strong belief that flour and wheat ought to only be sold to villagers of (a) nearby villages, and (b) sold first only to villagers in the market. During the transitionary period from pre-capitalist to capitalist economy, however, flour 
millers, farmers and bakers attempted to raise the price of white flour and white bread to maximise their own profits. According to Thompson (1971), they also increasingly sold their produce to farther regions at higher prices on preagreements These steps ran counter to existing social norms and moral assumptions which continued to be held by the poor. Consequently, the poor rioted.

This brief example of 18th century England highlighted two defining characteristics of moral economy theory. First, the theory takes a normative approach. It asks: (a) what economic activities are for, and (b) how they ought to take place. Such a perspective is in stark contrast to the positivist approach, which asks for mere descriptions of phenomena (Sayer 2007). Second, moral economy theory is closely connected to both political economy theory and to critical perspectives. Political economy theory explores how economic systems function, and how governments may steer such systems. Moral economy theory instead draws attention to the norms and values inherent to these economic systems, underlining that economies depend heavily on their social context (Mau 2003). As Polanyi (1944) describes, capitalist economic organisation remains embedded in social norms like precapitalist economies (see also Götz 2015). As such, moral economy theory shows that: (a) the details of economic activity are regulated by society, and (b) economic activities reflect social structures. This insight is central to critical perspectives (Bengtson et al. 1997).

Questions about the moral underpinning of economic activities regularly emerge when older individuals are considered. These considerations form their own vivid discourse within moral economy theory whichconstitutes the moral economy of aging. Frequently, the moral economy of aging concerns itself with questions of retirement. However, issues of (a) old age care, and (b) of the third age are also often considered. The third age refers to healthy retirement. The following paragraphs will outline the arguments made about each of these three topics.

\section{The moral economy of retirement}

The moral economy of retirement is at the core of the moral economy of aging. In modern Western societies, old age is defined as the time spent in retirement. Consequently, considering retirement means considering our understanding of old age itself. A moral economy perspective on retirement considers the norms and values associated with the transition into old age. It ponders when it would be fair to let people leave the workforce based on age. At the same time, it ponders when people ought to be supported through social security based on age, instead of generating their own income.

Kohli (1987) laid the groundworks for the moral economy of retirement with his historical case study of Germany. In this study, he considers the emergence and evolution of the German pension system from the perspective of moral assumptions. The emergence of the pension system institutionalized the life-course: it defined the age at which people were expected to work, and the age at which they are expected to withdraw from it. Moreover, it created perceived rules of reciprocity. The German pension system is pay-as-you-gofinanced which means that it redistributes resources from workers to pensioners at any given point of time. When people are of working age, they pay pension contributions which are redistributed to current pensioners. At the same time, the perception emerges that as these people pay their dues, society starts to owe them. Upon retirement, these individuals receive pension benefits, which are paid by current workers. Now older individuals receive the support that they are perceived to deserve. This arrangement creates a set of moral expectations and ideas about what is fair and what is not in terms of work and retirement. The moral economy of aging thus effectively segments individuals' life course into different parts of which each part has different expected roles to play and societal contributions to make within a broader structure of economic organization.

Moody (2009) argues that these expectations can be the cause of social tension whenever there are changes to pension arrangments. He uses the example of the United States, where pension savings were depleted in the wake of the 2008 financial crisis. In such situations, the material situation changes while moral expectations remain unchanged. As a result, the actual and the ideal situations diverge in people's minds which maysignal 
or create a perception of a lack of fairness across different age groups. For the same reason, pension reforms may create an impression of unfairness. Therefore, policymakers need to discuss them with greater circumspect (Arza and Kohli 2007).

\section{The moral economy of old age care}

A second prominent topic in the moral economy of aging concerns old age care. Because people often experience increased incidence of health problems as they age, the question of who provides care to them arises. A common perception is that this question is regulated through an intergenerational contract. This contract is a set of moral expectations and perceived rules of reciprocity within families. Within families, parents look after their young children. This activity can be perceived to oblige children to repay their parents later on: when parents reach old age, their children are expected to look after them (Breheny and Stephens 2012). In this way, parental and the filial generations support each other within the framework of moral economy.

In recent decades, women's workforce participation has increased. This shift entails that middle-aged women have less spare time, which they could use for old age care. Consequently, new caregivers are needed. While care services and nursing homes may substitute for some of the caring tasks, they are often either insufficient or pricey. Moreover, most frail older people prefer to stay at home over moving into a nursing home. This dilemma is sometimes solved with the help of migrant care workers. These migrants enter a country either legally or illegally to work as live-in caregivers to older people. Such an arrangement solves the need for old age care and it allows frail older people to keep living at home (Liang 2011; Shutes and Chiatti 2012). Using such care workers however raises the question of what had happened to the generational contract in caregiving, which sees the family unit as the prime caregivers to older individuals. Yet migrant care workers are frequently considered family members. This perspective suggests that the generational contract may indeed be fulfilled, and such older persons' needs are in fact handled in a fair way (Näre 2011).

\section{The moral economy of the third age}

A third topic in the moral economy of aging is third age. The third age refers to those years people spend as healthy retirees (Cuyvers et al. 2018). As healthy individuals, they would be physically capable of working for pay and some of them may in fact desire for meaningful activities which may include paid work. As retirees however, they are perceived to have fulfilled their duty to society and thus deserve a time of inactivity. Consequently, third-agers experience discordance between their situation and their social role. Because the third age has only started to emerge in recent decades, there is not yet any established set of activities specific to the third age, especially in relation to regular paid work. The current cohort of third-agers is currently creating these blueprints of activity patterns. A problem with this set-up is that the moral economy of retirement suggests that older individuals have already paid their dues to society. Bringing activities - especially activities that benefit society in one way or another - into the third age over existing moral perceptions of deserved inactivity would require changes in the current design of the moral economy of retirement (Komp 2011).

Policymakers are currently affected by the state of the moral economy of the third age. These policymakers are trying to increase the retirement age because of concerns about population ageing. Population ageing can exert financial pressure on pension schemes and it can reduce the size of the workforce. Both developments will slow down if people retire at a later age. Policymakers can use the existence of the third age as a justification for pension reforms, arguing that individuals are healthier even in later ages to work for a few additional years. However, the reform efforts nevertheless meet criticism for two reasons. Firstly, the moral economy of retirement with its associated norm of reciprocity across life course segments continues to be applied to third agers, making the reform efforts seem unfair. Secondly, not every individual becomes a third ager upon retirement - some do experience health problems before they move into retirement. Therefore, policymakers' argumentation does not hold true in all cases (Cuyvers et al. 2018; Komp 2011). In contrast, 
policymakers' efforts to support older volunteers fared much better. Furthermore these efforts aimed at supporting activities during the third age. However, these efforts did not touch upon the question of retirement: ie. they did not interfere with the social norms and moral assumptions of retirement. As a result, policymakers could highlight that they were increasing well-being and life-satisfaction in old age without actually shifting the moral norms underlying retirement. This argumentation resonates with the moral economy of the third age (Komp et al. 2013).

\section{Future Directions of Research}

Moral economy usually becomes a prominent topic whenever social change occurs. At these times, social structures change faster than their moral bases do, leading to discord and social tension. Discussions about morals and justice result. At the moment, population ageing drives fundamental social change, and it will continue to do so for years to come. Consequently, on-going discussions about pension reforms and about old age care will continue into the future. Research documents these discussions, and it may determine how to influence these discussions to make policy reforms more widely accepted. Also, the growing number of third agers calls for a new attitude towards older people, and for new opportunities for activities in old age. Research will need to observe how the moral economy of the third age gains ground, and it will also need to determine whether it replaces or supplements the extant moral economy of retirement.

\section{Conclusion}

Moral economy theory discusses the normative underpinnings of economic action. As a moral economy of aging, it describes the rights and expectations towards older people, outlining what is fair and what is not. At the moment, population ageing necessitates reforms especially in the areas of pensions and old age care, trigger moral economy discussions on these topics. However, the growing number of healthy retirees changes the discourse, highlighting the need to provide opportunities for activities in old age.

\section{Cross-References}

- Age stereotypes

- Critical gerontology

- Delaying retirement

- Formal/informal care

- Political economy of aging theory

- Social exchange theory

- Status of older people: Modernization

\section{References}

Arza C, Kohli M (eds) (2007) Pension reform in Europe: Politics, policies and outcomes. Routledge, New York

Bengtson V, Burgess E, Parrot T (1997) Theory, explanation and the third generation of theoretical development in social gerontology. J Gerontol Soc Sci 52B(2):S72-S88. doi:10.1093/geronb/52B.2.S72

Breheny M, Stephens C (2012) Negotiating a moral identity in the context of later life care. J Aging Stud 26(4):438-447. doi:10.1016/j.jaging.2012.06.003 
Cuyvers G, Thomese F, Van Tilburg T (2018) Participation narratives of Third Age adults: Their activities, motivations and expectations regarding civil society organisations. J Aging Stud 46:10-16. doi:10.1016/j.jaging.2018.05.003

Götz N (2015) 'Moral economy': Its conceptual history and analytical prospects. J Global Ethics 11(2):147162. doi:10.1080/17449626.2015.1054556

Kohli M (1987) Retirement and the moral economy: A historical interpretation of the German case. J Aging Stud 1(2):125-144. doi:10.1016/0890-4065(87)90003-X

Komp K (2011) The political economy of the third age. In Carr D, Komp K (eds) Gerontology in the era of the third ag. Springer, New York, pp 51-66

Komp K, Van Kersbergen K, Van Tilburg T (2013) Policies for older volunteers: A study of Germany and Italy 1990-2008. J Aging Stud 27(4):443-455. doi:10.1016/j.jaging.2013.10.003

Liang L-F (2011) The making of an 'ideal' live-in migrant care worker: recruiting, training, matching and disciplining. Ethn Racial Stud 34(11):1815-1834. doi:10.1080/01419870.2011.554571

Mau S (2003) Welfare regimes and the norms of social exchange. Cuur Sociol 52(1):53-74. doi:10.1177/0011392104039314

Moody H (2009) The moral economy of retirement. Generations 33(3):27-33

Näre L (2011) The moral economy of domestic and care labour: Migrant care workers in Naples, Italy. Sociology 45(3):396-412. doi:10.1177/0038038511399626

Sayer A (2007) Moral economy as critique. New Political Econ 12(2): 261-270. doi:10.1080/13563460701303008

POLANYI, K. 1957. The Great Transformation, Beacon Press.

Shutes I, Chiatti C (2012) Migrant labour and the marketisation of care for older people: The employment of migrant care workers by families and service providers. J Eur Soc Policy 22(4):392-405. doi: $10.1177 / 0958928712449773$

Thompson E (1971) The moral economy of the English Crowd in the Eighteenth century. Past Present 50(1):76-136. doi:10.1093/past/50.1.76 